\title{
HEDENIUS' SOTERIOLOGICAL ARGUMENT FROM EVIL
}

\author{
ANDERS KRAAL \\ University of British Columbia
}

\begin{abstract}
In this paper I explicate and assess a logical argument from evil put forth by the Swedish analytic philosopher Ingemar Hedenius in his book Tro och vetande (Eng. Faith and Knowledge) (1949), by far the most famous and influential critique of Christianity in Swedish intellectual history. I seek to show that Hedenius' argument is significantly different from, and indeed stronger than, the paradigmatic logical argument from evil in the analytic tradition, i.e. that of John Mackie (1955). Nevertheless, Hedenius' argument is, I argue, ultimately unconvincing.
\end{abstract}

This paper has three parts. In the first part I offer an explication of a logical argument from evil put forth by the Swedish analytic philosopher Ingemar Hedenius ${ }^{1}$ in his book Tro och vetande (Eng. Faith and Knowledge) (1949), by far the most famous and influential critique of Christianity in Swedish intellectual history. ${ }^{2}$ In the second part I compare Hedenius' argument with the paradigmatic logical argument from evil in the analytic tradition, namely that of John Mackie (1955),

\footnotetext{
${ }^{1}$ Hedenius (1908-1982) was Professor of Practical Philosophy at Uppsala University in 1947-1973, and one of the most influential Swedish intellectuals of his time. He was strongly influenced by David Hume, and wrote numerous philosophy books and papers in Swedish, and a few also in English, e.g. Sensationalism and Theology in Berkeley's Philosophy (Uppsala: Almqvist \& Wiksell, 1936) and Studies in Hume's Ethics (Uppsala: Almqvist \& Wiksell, 1937).

${ }^{2}$ To this day Hedenius is viewed by Swedish intellectuals as the chief 'prophet' of Swedish secularism; see e.g. P.C. Jersild, 'Bör man skilja på tro och vetande?', Dagens Nyheter (Nov. 9, 2002), Hans Ruin, 'Ingemar Hedenius: “Tro och vetande", Dagens Nyheter (Jan. 25, 2010), and Johan Lundborg, 'Den ständiga konflikten mellan tro och vetande', Svenska Dagbladet (Aug. 1, 2010). There is even a well-known saying in Swedish popular culture that goes: 'There is no God, and Hedenius is his prophet.'
} 
and seek to show that Hedenius' argument is significantly different from, and indeed stronger than, Mackie's argument. In the third part I examine some objections to Hedenius' argument put forth by Sebastian Rehnman (2002), and argue that these objections are unsuccessful, largely because they assume that Hedenius' argument has the same structure and content as Mackie's. Toward the end of the paper I seek to identify a main problem with Hedenius' argument.

\section{HEDENIUS' ARGUMENT}

Hedenius' argument from evil in (1949) aims at showing that the presence of evil in the world is logically inconsistent with the existence of 'the God of orthodox Christianity', and, hence, that the God of orthodox Christianity 'does not exist.' (By 'orthodox Christianity' Hedenius is not referring to Eastern Orthodoxy, but to traditional Christian theology as found, e.g., in traditional Lutheran theology.) In seeking to achieve this aim, Hedenius draws heavily on considerations pertaining to the Christian doctrine of salvation (as he understands it), and his argument could accordingly be described as a 'soteriological' argument from evil.

\subsection{The main passages}

I will begin by offering a survey of the main passages in which Hedenius states his argument. He begins his presentation by saying: ${ }^{4}$

(A) [Leibniz] believed that what is essential in Christianity could be defended against all purely logical objections. [...] He was of course aware of the intellectual difficulties that thinking people have always thought themselves to find in the Christian doctrine of redemption [...]. He also invested all his energy into solving these difficulties and declaring them void. But as to the failure of these attempts [...] there is little doubt. No critical person nowadays thinks that Leibniz once so famous solution in his Theodicy provides a satisfactory answer [...]. Is there any other and better answer? Not that I know of. Until a change comes about on this point I must be satisfied with formulating these

3 'den ortodoxa kristendomens Gud [...] existerar [inte]'; Ingemar Hedenius, Tro och vetande (Stockholm: Bonniers, 1949), p. 120. (All translation from Swedish into English in this paper are my own.)

${ }^{4}$ I will refer to the passages to be cited from Tro och vetande by the letters 'A', 'B', 'C', etc., so as to facilitate subsequent references. 
purely logical objections as clearly as I can and let the reader make a decision as to their cogency $[\ldots]^{5}$

Having made it clear that he takes the problem of evil to be a logical problem attaching specifically to the Christian doctrine of salvation, Hedenius goes on to develop his argument as follows. He first draws attention to Christianity's understanding of God's attributes of almightiness and perfect goodness:

(B) According to Christianity God is almighty [...] nothing occurs in the universe without having been willed or permitted by God. [...] Furthermore, God is perfectly good [...] [he] does [not] use his almightiness in a way that all fairly sensitive and enlightened people would unquestionably consider cruel and deeply unloving had a being in this world acted in the same way. ${ }^{6}$

Hedenius then proceeds to state the argument as follows:

(C) An obvious absurdity emerges when these two points of the Christian faith are joined to that part of the same faith that deals with the condition and state of human beings. The decisive feature of the condition and state of human beings is supposed to be [...] that humans have sinned against God and can only be saved from this horrible guilt of sin - the consequences of which must otherwise be horrific for the sinner because of God's unappeasable wrath - by a plan of salvation that depends on intervention by God himself. ${ }^{7}$

5 '[Leibniz] trodde, att det väsentliga i kristendomen kan försvaras mot alla rent logiska invändningar. [...] Naturligtvis var även han underkunnig om de tankesvårigheter, som tänkande människor alltid tyckt sig finna i själva den kristna försoningsläran [...] Han lade också ner hela sin energi ... på att lösa dessa svårigheter och förklara dem obefintliga. Men om det misslyckade i detta försök [...] torde det inte råda något tvivel. Ingen kritisk människa uppfattar numera Leibniz’ en gång så berömda Théodicée som ett tillfredsställande svar [...] Finns det något annat svar som är bättre? Intet som jag känner till. Intill dess en förändring härutinnan uppkommit måste jag nöja mig med att formulera dessa rent logiska invändningar så klart jag kan och låta läsaren ta ställning till dem själv. Hedenius, Tro och vetande, pp. 90-91.

6 'Enligt den kristna religionen är Gud allsmäktig ... ingenting sker i universum utan att vara velat eller medgivet av Gud. [...] Vidare är Gud fullkomligt god [...] [han] använder [inte] sin allmakt på ett sätt som av alla någorlunda känsliga och upplysta människor utan tvekan skulle betraktas som grymt eller grovt kärlekslöst, om en varelse av denna världen betedde sig på ett liknande sätt.' Hedenius, Tro och vetande, pp. 91-92.

7 'En uppenbar absurditet kommer emellertid i dagen, när de nu återgivna två delarna av den kristna tron sammanförs med den delen av samma tro, som närmare handlar om 
The above conclusion, i.e. that there is an 'obvious absurdity' in the Christian doctrine of salvation in view of God's almightiness and perfect goodness, recurs repeatedly in the passages following the above quotation (although in different words):

(D) Irrespectively of how one views it, this religion seems to be a mistake, simply because it appears to be an incoherent mess from a logical point of view as soon as we remind ourselves what kind of being this God is supposed to be. He is supposed to be not only almighty but also perfectly loving towards people. ${ }^{8}$

(E) Even if one, as is often the case nowadays, chooses not to believe in the idea of Adam and the Devil [...] who through Eve engaged in deception and hereby caused the passing on of sin against God to all mankind [...] our wickedness remains from a religious perspective a state that God in his almightiness allows us to be in. At the same time God could, if he had wanted to, have created all and only friends unto himself instead of sinners and criminals. ${ }^{9}$

(F) There is a saying that stems from antiquity and which Leibniz' opponent Voltaire also used. It goes like this: if God is almighty, it follows that he is not perfectly good, and if he is perfectly good, it follows that he is not almighty. In precisely this way one can bring to mind that basic idea of Christianity which makes this religion contradict eternal truth. ${ }^{10}$

människornas villkor och öden. Det avgörande i människans villkor och öden skulle ju [...] vara att alla människor har syndat emot Gud och att enda sättet att få befrielse från denna syndaskuld, vars konsekvenser på grund av Guds oblidkeliga hat mot synden annars måste bli fruktansvärda för den enskilde, är en frälsningsprocedur, som beror på en rad ingripanden av Gud själv.' Hedenius, Tro och vetande, p. 94.

8 'Hur man än vrider och vänder på denna åskådning tycks den vara ett misstag, helt enkelt därför att den framstår som ett sammelsurium ur logisk synpunkt, så snart vi erinrar oss vad slags väsen denne Gud samtidigt skall vara. Han skall ju inte bara vara allsmäktig utan också fullkomligt kärleksfull mot människorna.' Hedenius, Tro och vetande, pp. 94-95.

9 Även om man, som numera ofta sker, avstår från föreställningen om Adams av djävulen [...] anstiftade förförelse genom Eva och hela människosläktets på grund därav nedärvda synd mot Gud [...] så blir vår ondska ur religiös synpunkt ett öde som Gud i sin allmakt låter påvila oss. Samtidigt innebär denna allmakt att han mycket väl hade kunnat ge oss ett annat öde. Om han hade velat det, och han kunde ha velat det, så skulle han i stället för ett släkte av syndare och brottslingar, som blivit hans egna fiender, ha skapat idel vänner till sig.' Hedenius, Tro och vetande, p. 95. 
(G) That the God of orthodox Christianity does not exist can be proven from the circumstance that this God has contradictory attributes; he is both loving and unloving, almighty and not almighty. ${ }^{11}$

As can be seen, the above passages countenance the conclusion that orthodox Christianity is 'a mistake', 'an incoherent mess' (passage D), 'inconsistent with eternal truth' (passage F), and 'logically contradictory' (passage G) - simply put, that orthodox Christianity is false.

\subsection{The structure of the argument}

The main structure of Hedenius' above argument seems to be as follows. Christianity claims that God is almighty and perfectly good. An almighty God could have prevented the fall of mankind into sin and its consequent need of salvation (passage E). And, assuming that we understand the term 'good' in a fairly sensitive and enlightened way, a perfectly good God would have prevented mankind's fall into sin (passages B and D). But according to Christianity, God has not prevented this, so either God is not almighty or he is not perfectly good (primarily passage C). However, Christianity holds that God is both almighty and perfectly good; hence, Christianity is contradictory (primarily passage $\mathrm{G}$ ). In brief outline:

(1) Christianity claims that (i) God is almighty and perfectly good, and that (i) mankind has fallen into sin and can be saved only through God's plan of salvation.

(2) God's plan of salvation entails that God is not both almighty and perfectly good, for an almighty being could have prevented the Fall, and a good being - provided the term 'good' is understood in a fairly sensitive and enlightened way - would have prevented the Fall.

(3) Hence Christianity entails that God is almighty and perfectly good and that God is not both almighty and perfectly good. (From 1 and 2.)

(4) Hence Christianity is contradictory, and hence false. (From 3.)

10 'Det finns ett från antiken härstammande talesätt, som redan Voltaire, Leibniz' opponent, använde. Det lyder: om Gud är allsmäktig, så följer att han inte är allgod, och om Gud är allgod, så följer att han inte är allsmäktig. Just så kan man påminna om den grundtanke i kristendomen, som gör att denna religion strider mot vad som är evig sanning.' Hedenius, Tro och vetande, p. 101. (By 'eternal truth' Hedenius is referring to the laws of logic.)

11 'Att den ortodoxa kristendomens Gud inte existerar, det kan visserligen bevisas, emedan denne Gud har logiskt oförenliga egenskaper; han är ju både kärleksfull och icke-kärleksfull, allsmäktig och icke allsmäktig.' Hedenius, Tro och vetande, p. 120. 
The core claim of Hedenius' argument seems to be that the almighty and perfectly good God of orthodox Christianity could and would have prevented the Fall, and that, therefore, the God of orthodox Christianity does not exist, since the Fall has not been prevented. A core assumption, moreover, is that the term 'good' (or 'goodness') is understood in a fairly sensitive and enlightened way when orthodox Christianity predicates perfect goodness of God.

\section{THE RELATIVE STRENGTH OF HEDENIUS' ARGUMENT}

I proceed now to compare Hedenius' argument with Mackie's logical argument from evil, intending hereby to show that Hedenius' argument is the stronger one. Mackie's argument is no doubt the most famous logical argument from evil in modern analytic philosophy. It is drawn upon by recent defenders of the logical argument from evil such as Michael Martin, ${ }^{12}$ and is also the chief argument to which Alvin Plantinga responds in developing his famous Free Will Defence ${ }^{13}$ (a defence which many contemporary philosophers of religion consider decisive).$^{14}$

\subsection{Mackie's argument}

Mackie's argument from evil finds succinct summary in his claim that the three propositions

(5) 'God is omnipotent',

(6) 'God is wholly good',

(7) 'evil exists'

constitute a 'contradiction'. He says:

There seems to be some contradiction between these three propositions, so that if any two of them were true the third would be false. But at the same time all three are essential parts of most theological positions; the theologian, it seems, at once must adhere and cannot consistently adhere to all three. ${ }^{15}$

12 Michael Martin, Atheism: A Philosophical Justification (Philadelphia: Temple University Press, 1990), pp. 362-391.

${ }^{13}$ Alvin Plantinga, God, Freedom and Evil (Grand Rapids: Eerdmans, 1977), pp. 12-24.

${ }^{14}$ See e.g. William Alston, 'The Inductive Argument from Evil and the Human Cognitive Condition', in The Evidential Argument from Evil, ed. Daniel Howard-Snyder (Bloomington: Indiana University Press, 1996), pp. 97-125 (p. 97); William Rowe, 'In Defense of “The Free Will Defense", International Journal for Philosophy of Religion, 44 (1998), 115-120 (p. 115); and William Peterson, God and Evil: An Introduction to the Issues (Boulder: Westview Press, 1998), p. 47. 
This, then, is the basic idea of Mackie's argument from evil. (In order to derive a contradiction from (5)-(7) Mackie makes use of the principles 'a good thing always eliminates evil as far as it can' and 'there are no limits to what an omnipotent being can do. ${ }^{16}$ These additional principles have no impact on the comparison of Mackie's and Hedenius' arguments that I shall make, however, and shall therefore be left aside.)

\subsection{Comparison with Hedenius' argument}

There are both similarities and differences between Hedenius' and Mackie's respective arguments. A similarity is that both arguments seek to point out a logical contradiction between certain propositions pertaining to God and a proposition pertaining to evil. Both arguments are thus so-called logical arguments from evil (as opposed to, say, evidential arguments from evil).

A difference, however, concerns the conclusions of the respective arguments. Whereas Mackie's argument issues in the conclusion that 'God' does not exist, Hedenius' argument issues in the more specific conclusion that 'the God of orthodox Christianity' does not exist. Hedenius' argument is accordingly explicitly anti-Christian in a way that Mackie's is not.

A further and related difference is that Hedenius' argument draws heavily on themes pertaining to Christian soteriology, whereas Mackie's argument says nothing at all, and presupposes nothing at all, with regard to Christian soteriology. All that Mackie presupposes that overlaps with Christian theology is that God is 'almighty' and 'perfectly good'.

In the next section I shall argue that Hedenius' argument is stronger than Mackie's.

\subsection{The relative strength of Hedenius' argument}

As was noted above, a core claim of Hedenius' argument is that the almighty and perfectly good God of orthodox Christianity could and would have prevented the Fall, and that, since the Fall has not been prevented, the God of orthodox Christianity does not exist. This claim makes Hedenius' argument very different from Mackie's, which does not presuppose any theology of the Fall, but relies instead on the simple proposition that 'evil exists'. This difference, I believe, renders Hedenius'

${ }^{15}$ John Mackie, 'Evil and Omnipotence', Mind, vol. 64, no. 254 (1955), 200.

${ }^{16}$ John Mackie, 'Evil and Omnipotence', p. 200. 
argument stronger than Mackie's, for in this way Hedenius manages to avoid two controversial presuppositions of Mackie's argument.

The two controversial presuppositions of Mackie's argument that I have in mind are:

(i) that it presupposes a controversial ontology of evil; and

(ii) that it presupposes that God's almightiness entails an ability to rule over the actions of free agents, which many consider logically impossible.

In what follows I show that Hedenius' argument presupposes neither of these two things.

Consider first the presupposition of an ontology of evil. According to such an ontology there are such things as evils, that is, among the things that exist and make up the 'furniture of the universe' there are such things as 'evils' (be they abstract or concrete and particular makes no difference). This presupposition is rejected by a significant strand of Christian theologians from Augustine onward, according to which evil is a privation or absence of good (privatio bono) rather than a positive existence. ${ }^{17}$ Since Hedenius' argument does not use the premise that 'evil exists', it does not presuppose an ontology of evil, and so cannot be objected to on the ground that evil is not a positive existence. This, then, is a first strength of Hedenius' argument over against Mackie's.

Consider next the presupposition that God's almightiness involves an ability to rule over the actions of free agents. Mackie's argument presupposes that God's almightiness entails an ability to prevent 'evil' (any evil), and hence an ability to prevent the evil that may result from the actions of free agents. This entailment has long been considered a chief weakness of Mackie's argument by critics of the argument such as Plantinga, who argue that God 'can't cause or determine' creatures who 'are significantly free', for 'if He does so, then they aren't significantly free after all.'18 Hedenius' argument does not presuppose that God's almightiness entails that God is able to rule over the actions of free agents, it only presupposes that God was able to prevent the occurrence of one particular historical event, namely the Fall, and God's ability to prevent the Fall need not be tied to any ability to rule over the actions of free agents. (After all, the Fall might have been prevented in numerous

\footnotetext{
${ }^{17}$ On the privatio bono view, see John Hick, Evil and the God of Love (London: The MacMillian Press, 1988), pp. 38-58.

${ }^{18}$ Plantinga, God, Freedom and Evil, p. 30.
} 
ways other than ruling over the actions of free agents.) So for this reason too, Hedenius' argument seems to be the stronger one.

\section{CRITICISMS OF HEDENIUS’ ARGUMENT}

I turn now to criticism of Hedenius' argument. I begin by considering some objections to Hedenius' argument put forth by Rehnman in (2002), and argue that these objections are unconvincing. After that I propose a new objection, which I think identifies a problem with Hedenius' argument.

\subsection{Rehnman's explication}

Rehnman's main contention in (2002) is that Hedenius never succeeds in formulating or proving the presence of an inconsistency in Christianity. ${ }^{19}$ However, contrary to the explication given in Section 1.2, Rehnman does not treat Hedenius' argument as containing any premises pertaining specifically to Christian soteriology (although he does say, in passing, that themes pertaining to Christian theology are a part of Hedenius' understanding of the problem of evil). ${ }^{20}$ Instead, Rehnman understands Hedenius' argument as consisting in an attempt to derive a contradiction from the following three propositions: ${ }^{21}$

(8) God exists and is almighty.

(9) God exists and is perfectly good.

(10) There is evil in the world.

\section{Rehnman says:}

Taken together [8]-[10] are held to give rise to the logical problem of evil; two of the propositions in this set can be thought to be compatible, but not together with the third one. Hedenius accordingly holds that it is necessary for the Christian to deny the conjunction of these propositions. $^{22}$

19 Sebastian Rehnman, Gud, kunskap och vara: Kunskapsteori och metafysik hos Ingmar Hedenius (Nora: Nya Doxa, 2002), p. 297.

${ }^{20}$ Rehnman, Gud, kunskap och vara, p. 193.

21 '(1) Gud existerar och är allsmäktig (2) Gud existerar och är allgod och (3) Det förekommer ondska i världen.' Rehnman, Gud, kunskap och vara, p. 194.

22 'Sammantagna anses (1)-(3) ge upphov till det ondas logiska problem; två av i denna mängd ingående påståenden kan tänkas vara förenliga, men inte tillsammans med det tredje. Hedenius menar följaktligen att det är nödvändigt att för den kristne att förneka konjunktionen av dessa påståenden.' Rehnman, Gud, kunskap och vara, p. 194. 
(10) here takes over the role played by (2) in Section 1.2, i.e. the role of pushing the Christian concept of God to a contradiction. Interestingly, (10) is extracted from the same passage from which (2) is extracted, i.e. passage E. Rehnman seems to think that the soteriological themes in passage E do not figure in Hedenius' argument as such, but merely provide the context for extracting the claim that there is evil in the world.

This is a mistake, however, for Hedenius makes it clear that his argument from evil pertains specifically to Christian soteriology - as is seen e.g. in passages $\mathrm{A}, \mathrm{C}$ and $\mathrm{E}$. The soteriological themes in these passages are crucial to Hedenius' argument, whereas, on the other hand, the proposition that 'there is evil' does not figure in Hedenius' argument at all. This fact is also noted by Johan Lundborg in his book on Hedenius:

Hedenius' theodicy [by which is meant Hedenius' argument from evil] does not take its vantage point in the presence of evil in the world, but in the circumstance that God's attributes are incompatible with salvation history. ${ }^{23}$

Rehnman's misunderstanding of the basic structure of Hedenius' argument from evil results in corresponding mistakes in his objections to the argument, as we shall see below.

\subsection{Rehnman's first objection}

A first objection of Rehnman's is as follows:

In contrast to Mackie (1955: 26), Hedenius' position in Faith and Knowledge is that there is an 'obvious absurdity' among the elements of the set OLP [i.e. the set of premises (8)-(10)]. But the incompatibility or incompossibilitas is not, as e.g. Pike (1963: 40) and Plantinga (1967: 115-30; 1974a: 12-24; 1985: 38) have pointed out, obvious in first-order logic, nor is it explicit or formal. ${ }^{24}$

Rehnman seems here to assume that Hedenius, in using the expression 'obvious absurdity' in the above passage $\mathrm{C}$ (see Section 1.1), intends to say either

23 'Hedenius teodicé har således inte sin utgångspunkt i att det finns ont i världen utan i att Guds egenskaper inte går ihop med frälsningshistorien.' Johan Lundborg, När ateismen erövrade Sverige: Ingemar Hedenius och debatten kring tro och vetande (Nora: Nya Doxa, 2002), p. 72.

24 'Till skillnad från t.ex. Mackie (1955: 26) menar Hedenius i Tro och vetande att det föreligger en "uppenbar absurditet" mellan elementen i mängden OLP. Men incompossibilitas eller oförenligheten är inte, såsom bl.a. Pike (1963: 40) och Plantinga (1967: 115-30; 1974a: 12-24; 1985: 38) påpekar, uppenbar i första ordningens logik, ej heller vare sig explicit eller formell'. Rehnman, Gud, kunskap och vara, p. 194. 
(i) that there is an obvious contradiction between (11)-(13) in first-order logic; or that

(ii) there is an explicit or formal contradiction between the propositions (8)-(10), i.e. a conjunction of the form ' $p$ and not- $p$ '. (Apart from this assumption, there would be no point in introducing Pike's and Plantinga's contrasting observation with the word 'But'.)

But why think that Hedenius by 'obvious absurdity' had in mind a contradiction in first-order logic, or an explicit or formal contradiction? This assumption seems groundless. The term 'obvious' is ordinarily used in many ways other than to call attention to something that is clear in first-order logic or that is stated explicitly or formally. Why not think, say, that Hedenius in using this expression simply meant to say that the presence of a contradiction among the relevant propositions is not difficult to see? That it is not difficult to see a contradiction does not mean or entail that the contradiction is either explicit or formal, or that it is clear in first-order logic. For example, it is not difficult to see that the proposition that my only car is red contradicts the proposition that my only car lacks a colour; but there is nevertheless no explicit or formal contradiction here, nor do we get a contradiction if we assume a firstorder logic setting.

A deeper problem with the above objection, however, is that it simply gets Hedenius' argument wrong. Nowhere in the passages A-G in Section 1.1 does Hedenius ever explicate his argument from evil in terms of propositions of the sort (8)-(10), nor does he ever state that his argument from evil consists in pointing out a contradiction between such propositions. Rehnman's objection is therefore not merely unconvincing, it is irrelevant.

How are we to account for Rehnman's misunderstanding of the basic form of Hedenius' argument from evil? I believe the answer is indicated in the above quotation. Rehnman there assumes that Hedenius' argument from evil is essentially the same argument as Mackie's. And, indeed, the argument that Rehnman gives in terms of (8)-(10) is essentially the same argument as Mackie's (as should be clear from the survey of Mackie's argument in Section 2). But the argument of Mackie is, as we have seen, not that of Hedenius. By failing to note this, Rehnman ends up objecting to a straw man. 


\subsection{Rehnman's further objections}

Apart from the above objection, Rehnman levels various further objections to Hedenius' argument on the assumption that the argument from evil in (1949) is identical to one of Hedenius' later arguments from evil put forth in Om människans moraliska villkor (Eng. On the Moral Conditions of Man) (1972). In what follows I show that this assumption is mistaken, and that it once again renders Rehnman's objections to Hedenius' argument from evil in (1949) irrelevant.

In (1972) Hedenius presents the following argument from evil:

(11) If God exists, then our universe is the best possible $U$.

(12) With regard to any state of affairs $S$ which is such that there is some evil in $S$, it is the case that $S$ is not the best possible state of affairs, for another state of affairs $S^{\prime}$ such that $S^{\prime}$ contains just as much good ( 0 or $>0$ ) as $S$ and less evil than $S$, is always possible, and $S^{\prime}$ would be better than $S$.

(13) $U$ is a state of affairs;

(14) There is a large amount of evil in $U$.

(15) Hence $U$ is not the best possible $U$.

(16) Hence God does not exist. ${ }^{25}$

Rehnman takes this argument to be basically identical to the argument from evil in (1949). This is clearly a mistake, however, for the premises of the two arguments are very different from each other. In particular, the argument in (1949) involves no claims about a best possible world.

Unsurprisingly, Rehnman's objections to the argument in (1972) are simply irrelevant to the argument in (1949). The objections are:

(i) that the concept of the best possible world is logically contradictory;

(ii) that it is not 'essential to Christianity'26 to hold that God has created the best possible world;

25 '(1) Om Gud existerar, så är vårt universum det bästa möjliga $U$. (2) Beträffande varje sakförhållande, $S$, som är sådant att det finns något ont i $S$, gäller att $S$ inte är det bästa möjliga sakförhållandet, ty ett annat sakförhållande, $S$, som är sådant, att $S$ innehåller lika mycket gott $(0$ eller $>0)$ som $S$ och mindre ont än $S$ eller inget ont alls, är alltid möjligt, och $S^{\prime}$ skulle vara bättre än $S$. (3) $U$ är ett sakförhållande. (4) Det finns en stor mängd ont i $U$. (5) $U$ är inte det bästa möjliga $U$. Följer av (2), (3), (4). (6) Gud existerar inte. Följer av (1), (5). Hedenius, Om människans moraliska villkor, p. 267. (I have changed the numbering of Hedenius' premises in my translation so as to fit the numbering of the present paper; the same has been done with regard to the numberings of all passages from Hedenius and Rehnman quoted in this paper.) 
(iii) that it is not obvious that God is obliged to create the best logically possible universe or that God is not good if God does not create it; ${ }^{27}$ and

(iv) that the idea that the best possible universe must lack evil is highly doubtful. ${ }^{28}$

Neither of these objections are relevant to the argument in (1949) for the simple reason that that argument does not involve any premise about a best possible world.

I conclude, then, that Rehnman misunderstands Hedenius' argument from evil in (1949), and that his objections are impacted by this in a way that renders them largely irrelevant.

\subsection{A new objection}

I proceed now to develop a new objection to Hedenius' argument. The objection is directed at the argument's assumption that we understand the term 'good' in what Hedenius calls a 'fairly sensitive' and 'enlightened' sense. This assumption was inserted into premise (2) of the argument given in section 1.2 , i.e.:

(2) God's plan of salvation entails that God is not both almighty and perfectly good, for an almighty being could have prevented the Fall, and a good being - provided the term 'good' is understood in a fairly sensitive and enlightened way - would have prevented the Fall. It seems that there is an important ambiguity here. The ambiguity concerns whether this assumption (italicized above) is the assumption that

(i) we are to make in stating that orthodox Christianity claims that God is perfectly good, but which orthodox Christianity need not be assumed to make, or that

(ii) orthodox Christianity makes when it claims that God is perfectly good.

I believe it can be plausibly shown that if Hedenius understands the assumption in sense (i), his argument turns out logically invalid, whereas if he understands it in sense (ii), a crucial assumption of the argument turns out deeply problematic. In either case, then, the argument is in trouble.

26 'väsentlig för kristendomen.' Rehnman, Gud, kunskap och vara, p. 200.

27 'Men det är inte uppenbart att Gud är förpliktigad att skapa det logiskt bästa möjliga universumet eller att Gud inte är allgod om Gud inte skapar det.' Rehnman, Gud, kunskap och vara, p. 200.

28 'Tanken att det bästa möjliga universumet måste sakna ondska är därför en ytterst tveksam premiss.' Rehnman, Gud, kunskap och vara, p. 202. 
I seek first to show that if the assumption is to be understood in sense (i), the argument turns out logically invalid. This is so inasmuch as the argument is concerned with showing that 'orthodox Christianity' is self-contradictory, i.e. that orthodox Christianity entails, as in the inference (3) of the argument of Section 1.2, that God is almighty and perfectly good and not almighty and perfectly good. In order to make this inference - i.e. the inference of (3) from (1) and (2) - the sense in which God is 'good' (or 'perfectly good') in (1) and (2) must be the same, for otherwise we have a fallacy of equivocation. Since (1) simply reports what orthodox Christianity claims, the sense of 'good' in (1) is the sense of 'good' assumed by orthodox Christianity. Accordingly, if the sense of 'good' assumed in (2) - i.e. the 'fairly sensitive' and 'enlightened' sense - is not that of Christianity but of Hedenius' readers, then the argument is equivocal, and hence logically invalid. Hence to be logically valid, the argument must rest on the assumption as understood in the sense (ii), that is, on the assumption that orthodox Christianity, in predicating perfect goodness of God, is using the term 'good' in what Hedenius calls a 'fairly sensitive' and 'enlightened' sense.

I seek next to show that if we are to understand the assumption in the sense (ii), Hedenius' argument turns out problematic. This is clear from the following two considerations.

First, Hedenius provides us with no evidence that 'orthodox Christianity' understands the term 'good' in the relevant 'sensitive' and 'enlightened' sense when predicated of God. Hedenius refers to no Biblical texts, creeds, canons or influential theologians in support of this assumption. Instead, he simply takes the assumption for granted.

And secondly, there appears to be counter-evidence to Hedenius' assumption. That is, there is evidence for the counter-claim that orthodox Christianity understands terms like 'good' as having a special meaning when predicated of God, and, in particular, as not meaning what we would ordinarily mean when using the terms. As Thomas Aquinas argued, and as many traditional Catholics and Protestants have repeated after him, terms applied to God have analogous meanings; 'no name', says Aquinas, 'is predicated univocally of God and creatures.' ${ }^{29}$ The notion of 'analogous

${ }^{29}$ Thomas Aquinas, Summa Theologica (Salzburg: Verlag Anton Pustet, 1933), p. 64. (ST I, q13, a5.) For Protestant endorsements of the doctrine of analogy, see Robert Preus, The Theology of Post-Reformation Lutheranism, vol. 2 (St. Louis: Concordia Publishing House, 1970), pp. 39-45. 
meaning' is notoriously difficult to make precise, but it is at least clear that it is meant to entail that a term with an analogous meaning means something different from what it ordinarily or non-analogously means. 'Univocal predication', says Aquinas, 'is impossible between God and creatures. ${ }^{30}$ Now, since Hedenius' argument presupposes that orthodox Christianity understands the term 'good' in the relevant 'fairly sensitive' and 'enlightened' sense when predicated of God, and since, as we have just seen, this appears to run counter to the doctrine of analogy endorsed by many traditional Christian theologians, it follows that we have reason to think that Hedenius' argument rests on a mistaken presupposition, at least insofar as the relevant traditional Christian theologians are taken as representative of orthodox Christianity.

It could, of course, be questioned whether the relevant traditional Christian theologians should be taken as representative of orthodox Christianity. But then again, Hedenius has given us no reason to question this. So given this, and given that Hedenius provides us with no evidence for the assumption that orthodox Christianity understands the term 'good' in the relevant 'fairly sensitive' and 'enlightened' sense when predicated of God, it would seem that Hedenius' argument turns out problematic and unconvincing.

\section{SUMMARY}

In this paper I have offered an explication of Hedenius' argument from evil in (1949), and have argued that this argument is stronger than the paradigmatic logical argument from evil in the analytic tradition, namely Mackie's argument in (1955). It is 'stronger' inasmuch as it presupposes fewer controversial assumptions than Mackie's argument.

A core claim of Hedenius' argument was seen to be that the almighty and perfectly good God of orthodox Christianity would have prevented the Fall, and that, therefore, the God of orthodox Christianity does not exist, since the Fall has not been prevented. A core assumption was moreover that the term 'good' is understood in what Hedenius calls a 'fairly sensitive' and 'enlightened' sense when predicated of God.

I have argued that although the objections levelled at Hedenius' argument by Rehnman in (2002) are mistaken, Hedenius' argument is

\footnotetext{
${ }^{30}$ Thomas Aquinas, Summa Theologica, p. 64. (ST I, q13, a5.)
} 
still problematic. It is problematic in that the contradiction which it seeks to locate in orthodox Christianity can only be derived from orthodox Christianity on the assumption that orthodox Christianity uses the term 'good' in what Hedenius calls a 'fairly sensitive' and 'enlightened' sense when it predicates perfect goodness of God, and this assumption was seen to be problematic partly because it is left unargued and partly because it fits ill with the traditional theological doctrine of analogy. If this is right it would seem that Hedenius' argument, in spite of its strong points, is ultimately unconvincing. 